\title{
Green Intellectual Capital and Financial Performance of Manufacturing Companies in Indonesia
}

\author{
Erinos NR ${ }^{1}$, Yurniwati ${ }^{2}$ \\ ${ }^{1}$ Dept. of Accounting, Faculty of Economics, Universitas Negeri Padang, Padang, Indonesia \\ $\square$ (e-mail) erinos_nr@yahoo.co.id \\ ${ }^{2}$ Dept. of Accounting, Faculty of Economics, Universitas Andalas, Padang, Indonesia \\ $\bowtie$ (e-mail) erinosfeunp@gmail.com
}

\begin{abstract}
This study aims to find the influence of intellectual capital with financial performance in Indonesian Stock Exchange. The independent variable of this research is element of Green Intellectual Capital, consist of intellectual capital and corporate social responsibility (CSR). Intellectual capital calculation used public method, that is consisting of VACA (Value Added Capital Assets), VAHU (Value Added Human Capital), STVA (Structural Value Added). Corporate Social Responsibility (CSR) measured by action of corporate to public environment. Financial performance is measured by return on Assets (ROA). This research using secondary data from annual report. This research used multiple regressions that measured by Guilford standards value (1956). Research found that green intellectual capital has positive effect to financial performance but the effect is not significant. It is caused by imbalance investment in intellectual capital elements. Invest in human capital and then invest in STVA is high enough but invest in VACA is very low. CSR action by corporate is not influence to financial performance. They are more interested to low price and a high quality product. This study suggests, invest to intellectual capital must be balanced to achieve high financial performance in future and CSR action by corporate subject to increase people income.
\end{abstract}

Keywords: value added capital assets, value added human capital, structural value added, corporate social responsibility, financial performance

\section{Introduction}

The performance is results achieved by the management of operating activities that have been performed (Ingram, 2006). The above the average performance can be achieved by the company if the company has a competitive advantage and performance planning system (Kreklow, 2005). The best performance planning system is that links routines to the strategy (Chung et al, 2008). West et al (2010) describes the measurement of performance in the new context of is the synonymous with responsibility accounting. Performance is determined by actions taken by management. To achieve a high performance, organization should have an effective teamwork across departments within an organization (Ingram, 2006).

Many factors affect the financial performance, including the intellectual capital Intellectual defined as intangible assets owned by the company (Dalkir, et al, 2007; Blaise, et al, 2007; Ahangar, 2011; Ericson and Call 2008). Intellectual capital is a difference between the market value and the book value (Holland, 2009; Cezair, 2008). Research conducted by the researchers on the Intellectual Capital found different results. Intellectual capital positively influences on the performance (Ericson and Call, 2008; Shabarati et al., 2010; Helena, et al, 2010; Blaise et al. (2007) found intellectual capital negatively affect performance. Chang and Chen, (2012) argue to improve financial performance not only by intellectual capital, but also the surrounding environment as well as the concern for the environment. Thus, concept is known as the green intellectual capital (Chen, 2008; Chang and Chen, 2012). The companies must implement corporate social responsibility (CSR).

Research on CSR also finds difference results. Ameer and Othman (2012), Clacher and Hagendorff (2012), Jo and Harjoto (2012) found a positive effect between CSR and financial performance of the 
company. On the contrary Laan, Ees, Itteloostuijn (2008), Baird and Pinar (2012) found a negative influence. Other variables that also affect the performance is a non-executive director (board of commissioners). Maki et al. (2009) finds Intellectual capital positively impact the financial performance. Abidin, et al (2009) found independent commissioners have important role improving intellectual capital which leads to the difference financial performance.

In this study, green intellectual capital is a construct, so it does not become the object of this study, the analysis is only used to describe the magnitude of the effect of green intellectual and then relate to value analysis from Guilford (1956) so that it can be known high performance achieved, this can be found which elements influential form of financial performance - ROA.

The relationship between each of the independent variable and corporate performance is hypothesized as follows:

H1: VACA (Value Added Capital Asset) has effect on financial performance which is proxied by ROA.

H2: VAHU (Value Added Human Capital) effect on financial performance which is proxied by ROA

H3: STVA (Structural Capital Value Added) has effect on financial performance which is proxied by ROA

H4: Corporate Social Responsibility (CSR) effect on the financial performance of ROA

\section{Methods}

This study was performed on companies listed on the Stock Exchange. The number of companies that meet the criteria amounted to 117 units. When the analysis is done 11 companies do not meet the requirements, that totaling 106 companies were analyzed.

To calculate Value added is done reducing sales minus the cost of production but not including labor costs. Thus, it is seen that calculated value added value is the excess value of sales on the value of the raw materials that have been processed to finished goods. Measurement VACA done by calculating the value added compared to the total assets. Measurement VAHU calculated from the comparison of value added and the total direct and indirect labor costs. STVA measurement is the value added minus total labor costs compared with the value added itself. Corporate Social Responsibility, CSR is measured by looking at the activity of the company to implement its CSR reported in the financial statements. CSR measures being taken ISO 26000. If companies do given the value 1 , otherwise the value 0 . The calculation of ROA is done by calculating the net income compared to the total assets of the company.

\section{Results and Discussion}

Based on the descriptive test results for all variables presented shows that the financial performance. ROA with an average value of 0.0802 or $8.02 \%$. VACA, the average value is 0.3925 , this value is very low. VAHU is 4.633 , this value is very high, while STVA is 0.7208 , and the assessed value is quite high. CSR is 0.7208 or $72.08 \%$ of samples has implement the ISO 26000 standard. As an initial reference, the statistical analysis found that green intellectual capital affects the financial performance. $F$ test value is 0.000 and the coefficient of determination (Adj. R2) is 0.0219 , or $21.9 \%$. Based on the interpretation and percentage value can be seen the positive effect of green intellectual capital on the financial performance ROA, but the effect is very low because it is located in the quartile 1 . This is because the effect is below $40 \%$.

Based on the statistical results found VACA has positive and significant impact on financial performance ROA, with a P value is .000 and coefficient value test of .425 or $42.50 \%$. When associated with a table Guilford (1956), it can be categorized as the middle category because they are in quartile 2 , the percentage between $40 \%-60 \%$. The Results of statistical analysis found that the value added human capital (VAHU) has not positive and significant effect on the financial performance ROA. Ptest value of $0.118>0.05$, because it had no effect, the result is not associated with a table of Guilford. 
Results of statistical analysis found that structural capital value added (STVA) has no effect on the financial performance of ROA. This is due to the calculated value $\mathrm{P}$ is equal to .745. Results of statistical analysis found that the implementation of CSR by companies has not positive and significant impact on financial performance of ROA. P-value $804>0.05$, therefore this result is not associated with Guilford table.

\section{Discussions}

Results of statistical calculations explained that the green intellectual capital has significant and positive effect on the company's financial performance ROA controlled by comissioners independent. Although the result has a positive effect, but if it is related to the size stated by Guilford (1956) they are low due to the effect are below $40 \%(0.219)$. The effects are described in the discussion of the elements that make up the green intellectual capital.

\section{Value Added Capital Asset (VACA) Against Financial Performance}

Results of this study found VACA (value added capital assets) positive effect on the financial performance seen from the side ROA controlled by independent commissioner. VACA which is a form of the company's ability to manage its resources in the form of capital assets. VACA a value added obtained from the difference between the sales with the cost of production but does not include wage costs divided by total assets. VACA is the value added of the raw material after processed using machine production divided by total assets of the company. The expected value of the minimum is one to achieve high performance (top performers), which means the value added obtained is equal to the net value of existing assets.

VACA (value added capital assets) is the key to the success of the company to achieve the desire of shareholders and potential investors. This VACA become hope to be able to continue to exist in the world of business. Results of a descriptive study found that VACA average is only 0.3925 far below the expected.

The low value of VACA is a major source of failure of management to achieve high financial performance. VACA value is the lowest value among the elements of intellectual capital, but it is the only element of green intellectual capital that affect the financial performance of ROA. Its influence is quite high according to the value of Guilford table. The low value of this VACA could indicate several things: a. Efficiency and lack of effectiveness in the production process; $b$. The use of less sophisticated technology in the production process; c. The determination of the cost of production is not based on activity; d. Lack of management capabilities creates a different product with competitors.

The low value of VACA, causing management difficulties to increase profits. VACA reflects the assets owned are no longer productive. To improve VACA company must make an additional investment to sophisticated machines that are more capable of producing more efficient, cheaper and more attractive form so that the products attract more consumers to buy them. To increase VACA by the company is very necessary. Management creativity creates new products but still related to old products are needed. For example, add product function, reduce the size of the product or the other and will be seen by consumers as a new product as the improvement of old products.

\section{Value Added Human Capital (VAHU) against Financial Performance}

Results of statistical explained that VAHU (value added human capital) has no positive effect on the financial performance which is controlled by an independent commissioner. Descriptive the results statistical analysis showed very high VAHU value which is equal to 4.463 . This value is the highest among the elements of intellectual capital. VAHU high value reflects the company's employees who already have a high talent to run the company's operations. VAHU high value results high financial performance. VAHU explain human capital possessed by already have a high talent, but they are not supported by adequate facilities. The effect of the human capital cannot work 
effectively and efficient, in other words a high ability human capital cannot be used optimally because of the technology used by the company is still very old. Production manager cannot produce to fit the market demand for production machines (VACA) they have still old-fashioned technology and low capacity. The effect manager (VAHU) can only work in accordance with the capabilities of existing machines. These factors lead to low production performance. The so low performance VAHU that cause has no effect on the financial performance.

\section{Value Added Structural Capital (STVA) against Financial Performance}

Results of statistical analysis of the study explained that the Value Added Structural Capital (STVA) also had no effect on the financial performance. The average value of descriptive statistics for this STVA is 0.780 . This value is relatively high; to achieve the high performance required value of at least one, but the results of the study found there is no effect of this STVA. It can explain STVA has not influence on financial performance due to low (slightly) the level of work performed by this STVA. Low levels of employment due to the low value of the existing VACA. STVA related to corporate culture, management processes, information systems, networking systems, financial relations, customer loyalty, company names, and so on. This shows management process, information systems, networking systems owned could not run optimally. The effect is the company must pay a relatively large to process a simple task. Low STVA effect to the financial relations, customer loyalty, company names lower in the eyes of consumers.

If things like this are not recognized by management, the effect is the reduction of financial relations, customer loyalty; company names are lower in the eyes of consumers. If this continues then certainly the destruction of existing companies soon. To get out of this problem then the only way that can be taken is to invest in VACA. Companies must swap the old-fashioned machines with advanced and flexible machines, so STVA Company owned also runs effectively and efficiently.

\section{Corporate Social Responsibility (CSR) against Financial Performance}

Results of the study explained that the implementation of CSR did not affect the financial performance of ROA. There is not influential CSR implementation due to ignorance of Indonesian consumer society on the implementation of CSR. In the terms of the percentage of CSR implementation has been quite high.

Society of Indonesian consumers still choose the cheap product, high quality goods ignoring whether the product is manufactured by a company that runs CSR or not. Whether the companies is polluting the environment or not, they do not care. Meanwhile the government has made it compulsory for companies to implement CSR, but implementation is left to the company itself. Implementation of CSR by companies less brings economic change to the people close to the location of the plant. The provision of such assistance is only temporary and does not bring economic influence on the surrounding community, for example, for the celebration of August 17, to sponsor specific events. Thus, the lack of a standard size on the implementation of CSR issues is seen.

The different sizes CSR activities undertaken Indonesia, because until now there has been no agreement among experts on the definition of measurable on CSR, thus each company to translate the understanding of CSR in accordance with their own interests let execution delivered directly to the companies that run by the government, Thus the public at the location of the manufacture plant has not been felt the positive impact of the company's presence.

\section{Conclusions}

The low influence of green intellectual capital on the financial performance (ROA) due to lower VACA value of the company, in terms of VACA is the only variable that affects the company's financial performance. The low value of VACA caused other elements of green intellectual capital cannot work optimally. This is the reason why the company's performance is low. Low value VACA, high value STVA and VAHU, all of this explains the lack of balance in investment. So, companies 
have to change their mindset in investment. Investments should be balanced, the balance of investment will be able to create synergies to accelerate and improve financial performance.

Uninfluential implementation of CSR on financial performance, explains the Indonesian society consumer is less concerned to the environment due to the low level of their income. They only need high quality products and low prices. In addition, the implementation of CSR undertaken by the company is not touching their life, although the level of implementation is already quite high.

In the future, the company's management should recalculate its intellectual capital; it is useful to know the weaknesses in the company. Related to the implementation of CSR, the implementation of CSR should be related to the economic development of the surrounding communities so they can improve their economy. Thus, the existence of the company perceived by society so that it can create a sense of 'self of belonging' to the company.

\section{References}

Abidin, Z., Kamal, N., \& Yousof. (2009). Board structure and corporate performance in Malaysia, International Journal of Economic and Finance, 1(1), 150-164.

Ahangar, R. (2011). The relationship between intellectual capital and financial performance: An empirical investigation in an Iranian company. African Journal of Business Management, 5(1). 88-95.

Ameer, R. Othman. (2012). Sustainability practices and corporate financial performance: A study based on the top global corporations. Journal of Bussines Ethics, 108, 61-79.

Appuhami, A. (2007). The impact of intellectual capital on investors capital gains shares: An empirical investigation of Thai banking, finance and insurance sector. International Management Review, 3(2), 14-25.

Ashton, R. (2005). Intellectual capital and value creation: A Review. Journal of Accounting Literature, 24 53-134.

Baird, P. L., \& Pinar. (2012). Corporate social and financial performance re-examined: Industry effects in a linear mixed model analysis. Journal of Business Ethics, 109, 367-388.

Bernstein, L. A., \& Wild, J. J. (1998). Financial statement analysis: Theory, application, and interpretation. McGraw-Hill Book.

Birasnav, M. (2011). Transformational leadership and human capital benefits: The role of knowledge management. Leadership and Organization Development Journal, 32 (2). 106-126.

Blaise, M. S., Kerri, C., \& Carson, P. (2007). Accounting for intellectual capital: The relationship between profitability and disclosure. Journal of Applied Management and Entrepreneurship, 12(2), 314.

Cezair, J. A. (2008). Intellectual capital, hiding in plain view. Journal of Performance Management, 21(2), 29-40.

Chang, C. H., \& Chen. (2012). The determinants of green intellectual capital. Management Decision, $50(1), 74-94$.

Chen, Y. S. (2008). The positive effect of green intellectual capital on competitive advantages of firms. Journal of Business Ethics, 77, 271-286.

Chen, H. M., Lin, K. J. (2011). The role of human capital cost accounting. Journal of Intellectual Capital, 5(1), 116-130.

Choi, J. S., Min, K. Y., \& Chongwoo, C. (2010). Corporate social responsibility and corporate financial performance: evidence from Korea. Australian Journal of Management, 291-311.

Chung, L. L., Yau, O. H. M., Sin, L. Y. M., Alan, C. B., Tse, C. B. T., Chow, A. C., \& Lee, Y. S. (2008). The effects of social capital and organizational innovativeness in different institutional context, Journal of International Business Studies, 39, 589-612.

Clacher, J. Hagendorff. (2012). Do announcements about corporate social responsibility creator destroy shareholder wealth? Evidence from the UK. Journal of Business Ethics, 106, 253-266.

Dalkir, K., Wiseman, E., Shulha, M., \& Intyre, S. (2007). An intellectual capital evaluation approach in a government organization. Management Decision, 45 (9), 1497- 1520. 
Erickson, G. S., \& Call, M. M. (2008). Intellectual capital and the hospitality industry. Competition Forum, 6(1) 37-43.

Erickson, G. S., \& Call, M. M. (2012). Using intellectual capital to enhance performance in hospitality industry. ACR, 20 (1), 1158.

Esther, H., Canino, B. R., Sánchez, \& Agustín, M. (2011). The Impact of relational capital on the success of new business start-ups. Journal of Small Business Management, 49(4), 617-638.

Hagendorff, J., \& Clacher, I. (2012). Do announcements about corporate social responsibility creator destroy shareholder wealth? Evidence from the UK. Journal of Business Ethics, 106, 253-266.

Hazmi., A.M. (2010). Strategic Choices: The case of management accounting system. Journal of Applied Business Research, 26(6), 33-47.

Helena, S. R., Pedro, F. D. \& Jardon, C. F. (2010). The influence of human capital on the innovativeness of firms. The International Business and Economics Research Journal, 9 (9), 53-64.

Holland, J., Fund Management. (2006). Intellectual capital, intangibles and private disclosure. Managerial Finance Journal, 32 (4), 277-317.

Ingram, H., \& Donnell, B. M. (1996). Management effective performance management - The teamwork approach considered managing service quality, 6 (6), 38-42.

Jo, H., \& Harjoto, M. A. (2012). The causal effect of corporate governance on corporate social responsibility. Journal Business Ethics, 106. 53-72.

Kianto, A. \& Waajakoski, J. (2010). Linking social capital to organizational growth. Knowledge Management Research and Practice, 8(1), 4-15.

Kreklow, S. R. (2005). Using Performance Measures to Improve Performance. Government Finance Review, 2005, 21(6), 52-64.

Laan, G. V., Hans, V. E., \& Witteloostuijn, A. V. (2008). Performance: an extended stakeholder theory, and empirical test with accounting measures. Journal of Business Ethics, 2008, 79, $299-310$.

Maditinos, D. Chatzoudes, Sairidis, D., \& Theriou, T. (2011). The Impact of Intellectual Capital on Firms Market Value and Financial Performance. MIBES Transactions, 5(1), 58-72.

Luthan, E. (2011). Pengaruh kinerja sosial terhadap kinerja keuangan. Disertasi. Universitas Padjadjaran, Bandung.

Makki, M., Majid, M., Lodhi, A., \& Rohra, S. A. (2009). Impact of intellectual capital on shareholders earning. Australian Journal of Basic and Applied Sciences, 3 (4), 386-398.

Nugroho, Y. (2013). CSR dalam gagasan dan praktik. Kompas, 28 juni 2013, Klass 81.

Pulic. A. (2000). MVA and VAIC ${ }^{\mathrm{TM}}$ Analysis of randomly selected companies from FTSE 250. Austrian Intellectual Capital Research.

Pulic, A. (1998). Measuring the performance of intellectual potentialin knowledge economy. Presented in 1998 at the $2^{\text {nd }}$ McMaster World Congress on Measuring and Managing Intellectual Capital by the Austrian Team for Intellectual Potential.

Rakhiemah, N., \& Agustia, D. (2009). Pengaruh kinerja lingkungan terhadap csr disclosure dan kinerja finansial perusahaan manufaktur di BEI. Thesis.

Sharabati, A. A., Naji J. S., \& Bontis, N. (2010). Performance in the pharmaceutical sector of Jordan. Management Decision, 48(1), 105-131.

Tan, H., \& Lipe, M. (1997). Outcome effects: The impact of decision of process and outcome controllability. Journal of Behavioral Decision Making.

Yip, E., Staden, C. V., \& Cahan, S. (2011). Corporate social responsibility reporting and earnings management: The role of political costs. Australasian Accounting Business and Finance Journal, 5(3), 17-34. 